\title{
PENGEMBANGAN MEDIA PEMBELAJARAN BERBASIS ANDROID \\ MENGGUNAKAN APLIKASI ADOBE FLASH CS 6 PADA \\ MATA PELAJARAN SOSIOLOGI
}

\author{
Anita Adesti ${ }^{1}$, Siti Nurkholimah ${ }^{2}$ \\ ${ }^{1,2}$ Universitas Baturaja \\ 1anitaadesti@gmail.com, 2.nurkholimah.siti25@gmail.com
}

\begin{abstract}
Abstrak
Perkembangan ilmu pengetahuan dan teknologi, khususnya di bidang teknologi informasi dan komunikasi telah memberikan kemudahan dalam meningkatkan kualitas pendidikan. Penggunaan smartphone android oleh siswa sebagai media komunikasi menjadi salah satu potensi yang bisa dikembangkan untuk menunjang pembelajaran bergerak secara virtual di Sekolah Menengah Atas. Tujuan penelitian ini yaitu: (1) mengembangkan media pembelajaran berbasis android dengan menggunakan Adobe Flash CS 6 pada mata pelajaran Sosiologi guna meningkatkan motivasi belajar siswa di kelas X SMA; (2) menguji kelayakan media pembelajaran berbasis android dengan kriteria baik (layak) dan praktis. Jenis penelitian yang digunakan yaitu penelitian dan pengembangan (research and development) dengan model pengembangan prosedural yang diadaptasi dari model pengembangan Sugiyono dan Warsita yang meliputi (1) tahap perancangan, (2) tahap produksi media, dan (3) tahap evaluasi. Hasil penelitian menunjukkan bahwa (1) dihasilkannya media pembelajaran berbasis android pada mata pelajaran Sosiologi; (2) media pembelajaran berbasis android layak digunakan hal ini sesuai dengan hasil uji ahli media 80,45 (baik), uji ahli desain 81,90 (baik), uji ahli materi 88,41 (baik) selanjutnya uji skala perorangan 91,25 (praktis), uji skala kecil 86,35 (praktis) dan uji produk lapangan 80,43 (praktis).
\end{abstract}

Kata Kunci: Media Pembelajaran; Android; Sosiologi.

\begin{abstract}
The development of science and technology, especially in the field of information technology and communication has provided ease in improvement the quality of education. The use of an android smartphone by students as a medium of communication becomes one of the potential that can be developed to support the learning of virtual moves in high school. The purpose of this research is: (1) Develop Android-based learning media by using Adobe Flash CS 6 on sociology subjects to improve student motivation in X-grade SMA (2) test the feasibility of Android-based learning media with valid and practical criteria. The type of research used is research and development with a procedural development model adapted from the model of Pustekom's development according to Warsita, which includes (1) planning stages, (2) Stages of production or development of media, and (3) the assessment or evaluation stage. The results showed that (1) the media-based learning of Android in sociology subjects (2) Android-based learning media deserves to be used in accordance with the test results of the media experts 80.45 (good), 81.90 design Expert test (good), material expert test 88.41 (good)
\end{abstract}


Edutainment : Jurnal Ilmu Pendidikan dan Kependidikan

Volume 8 Nomor 1 Edisi Januari - Juni 2020

subsequent individual scale test 91,25 (practical), small scale test 86.35 (practical) and test field product 80.43 (practical).

Keywords: Instructional Media; Android; Sociology.

\section{PENDAHULUAN}

Pembelajaran (belajar dan mengajar) merupakan komunikasi antar guru dan siswa. Komunikasi pada proses pembelajaran yaitu siswa, sedangkan komunikatornya yaitu guru dan siswa. Untuk mengurangi kemungkinan terjadinya salah komunikasi maka diperlukan alat bantu (sarana) yang dapat membantu proses komunikasi. Sarana tersebut yaitu media.

Proses pembelajaran seringkali dihadapkan dengan media dan sumber materi didapatkan oleh mahasiswa baik dalam kurangnya kelengkapan sumber materi seperti buku cetak dan tingginya harga perangkat media pembelajaran. Agar pembelajaran lebih efektif dan efisien dibutuhkan multimedia yang tepat dalam proses pembelajaran. Multimedia dapat berbeda dari sudut pandang orang yang berbeda secara umum, multimedia berhubungan dengan penggunaan lebih dari satu macam media untuk menyajikan informasi (Muyaroah dan Fajartia, 2017).

Menurut Hamdani (2011) "Media adalah perantara atau pengantar pesan dari pengirim dan penerima". Gerlach dan Ely dalam Hamdani (2011) mengatakan "Media apabila dipahami secara garis besar adalah manusia, materi, atau kejadian yang membangun kondisi yang membuat siswa mampu memperoleh pengetahuan, keterampilan, atau sikap".

Peranan sebuah media dalam pembelajaran dikatakan sangat penting, yakni dapat memperjelas penyajian pesan informasi yang bisa memperlancar proses belajar dan meningkatkan hasil belajar, serta mengarahkan perhatian peserta didik, sehingga menimbulkan motivasi belajar untuk belajar mandiri sesuai dengan kemampuan dan minatnya.

Menurut Noer (2016) "Sosiologi adalah ilmu yang mempelajari tentang masyarakat. Sosiologi yang dimaksud dalam penelitian ini adalah salah satu mata pelajaran pada jenjang Sekolah Menengah Atas (SMA) yang mempelajari tentang masyarakat, meliputi interaksi sosial, stratifikasi sosial, konflik dan integrasi sosial, globalisasi dan modernisasi, dan perubahan sosial budaya masyarakat dalam kehidupan sehari-hari”.

Fenomena terjadi di lapangan pada saat proses pembelajaran peserta didik menggunakan smartphone android sebagai kegiatan di jeda pembelajaran. Sedangkan yang kita ketahui smartphone android merupakan alat elektronik yang tidak bisa dipisahkan dalam kehidupan manusia. 
Edutainment : Jurnal Ilmu Pendidikan dan Kependidikan

Volume 8 Nomor 1 Edisi Januari - Juni 2020

Karena smartphone android tersebut merupakan kebutuhan bagi setiap individu pada era digital seperti untuk hiburan bermaingames, mendengar musik, chatting di sosial media, dan juga browsing untuk mencari pengetahuan sosial maupun mata pelajaran.

Penggunaan mobile smartphone berbasis android menjadi sebuah tantangan yang menyinggung kebiasaan hidup dan cenderung sulit dipisahkan dalam kehidupan masyarakat dari segala usia. Hal ini dikarenakan mobile smartphone berbasis android menjadi kebutuhan primer mayoritas masyarakat. Fenomena yang dirasakan secara nyata saat ini yaitu orang cenderung menghabiskan waktu dengan smartphone android-nya dan menjadikan android semakin popular (Ningsihdan Adesti, 2019).

Popularitas aplikasi android ini disebabkan oleh beberapa faktor yaitu faktor kecepatan yang memudahkan user untuk mengakses data yang dibutuhkan, menyediakan akses untuk mengatasi masalah yang dihadapi, memiliki desain yang kreatif dan user friendly atau mudah digunakan, serta dapat digunakan secara fleksibel dan dapat diandalkan untuk segala kebutuhan informasi (Istiyanto, 2013). Melihat fenomena tersebut peneliti mengembangkan media pembelajaran dengan menggunakan android sebagai media dalam proses pembelajaran yang akan disampaikan. Pengembangan media pembelajaran berbasis android diharapkan mampu meningkatkan motivasi belajar siswa dikarenakan saat ini proses pembelajaran dengan media konvensional pada mata pelajaran ilmu sosial cenderung membuat siswa tidak termotivasi dalam belajar, sejalan dengan peluang penggunaan smartphone android dikalangan remaja yang saat ini sangat tinggi, maka diharapkan media pembelajaran berbasis android ini bisa menjadi alternatif bagi guru atau pun siswa untuk lebih bersemangat lagi dalam melaksanakan kegiatan belajar mengajar dengan teknologi digenggaman.

Pengembangan media pembelajaran berbasis android ini berdasar beberapa pertimbangan: a) dapat dijadikan media belajar mandiri bagi peserta didik baik di sekolah maupun di luar sekolah, b) dapat digunakan oleh pendidik sebagai media pembelajaran dalam proses belajar mengajar (Kuswanto dan Radiansyah, 2018).

Menurut Safaat (2015), “Android adalah sebuah sistem operasi untuk perangkat mobile berbasis linux yang mencakup sistem operasi, middleware, dan aplikasi".

Di dalam kawasan pengembangan terdapat keterkaitan yang kompleks antara teknologi dan teori yang mendorong baik dari segi desain, pesan maupun strategi 
Edutainment : Jurnal Ilmu Pendidikan dan Kependidikan

Volume 8 Nomor 1 Edisi Januari - Juni 2020

pembelajaran, yang bertujuan untuk merancang sebuah sistem pembelajaran dan pengembangannya ke dalam sistem pembelajaran dan harapannya nanti hasil dari desain dan pengembangan suatu sistem dapat dimanfaatkan atau dipergunakan dalam sistem pembelajaran.

\section{METODE PENELITIAN}

Jenis penelitian yang digunakan yaitu penelitian pengembangan. Menurut Sugiyono (2012) metode pengembangan (Research and Development) yaitu "Penelitian yang digunakan untuk menghasilkan produk tertentu, dan menguji keefektifan produk tersebut".

Penelitian ini bertujuan untuk memanfaatkan software yang telah ada dengan membuat suatu program dalam bentuk media belajar menggunakan adobe flash CS 6 untuk meningkatkan motivasi serta prestasi siswa dalam belajar dan pembelajaran. Setelah itu, dilakukan evaluasi kelompok kecil, kemudian selanjutnya uji coba lapangan.

Instrumen penelitian menggunakan kuesioner (angket). data angket dianalisis menggunakan skala likert dan menggunakanrumus persentase:

$$
p=\frac{f}{N} X 100
$$

(Sudijono, 2011)
Keterangan:

$f=$ Frekuensi yang sedang dicari persentasenya

$\mathrm{N}=$ jumlah frekuensi / individu

$p=$ angka persentase $\%$

Tabel 1. Kriteria Penentuan dengan

Penghitungan

\begin{tabular}{|c|c|c|}
\hline Interval & Nilai & \\
\hline Persentase & Ubahan & $\mathrm{e}$ \\
\hline Tingkat & Skala & eterang \\
\hline Penguasaan & Empat & \\
\hline
\end{tabular}

\begin{tabular}{cccl}
\hline $86-100$ & 4 & A & Baik sekali \\
$76-85$ & 3 & B & Baik \\
$56-75$ & 2 & C & Cukup \\
$10-55$ & 1 & D & Kurang
\end{tabular}

Nurgiyantoro (2010)

Tabel 2. Range Skor Hasil Presentasi Validasi Produk

\begin{tabular}{ccl}
\hline $\begin{array}{l}\text { Tingkat } \\
\text { Pencapaian }\end{array}$ & Kualifikasi & Keterangan \\
\hline $90 \%-100 \%$ & $\begin{array}{c}\text { Sangat } \\
\text { Baik }\end{array}$ & $\begin{array}{l}\text { Tidak perlu } \\
\text { direvisi }\end{array}$ \\
\hline $75 \%-89 \%$ & Baik & $\begin{array}{l}\text { Direvisi } \\
\text { seperlunya }\end{array}$ \\
\hline $65 \%-74 \%$ & Cukup & $\begin{array}{l}\text { Cukup } \\
\text { banyak } \\
\text { direvisi }\end{array}$ \\
\hline $55 \%-64 \%$ & Kurang & $\begin{array}{l}\text { Banyak } \\
\text { direvisi }\end{array}$ \\
\hline $0-54 \%$ & Sangat & Direvisi total \\
& Kurang & Tegeh (2014)
\end{tabular}


Dalam penelitian ini penilaian validasi produk meliputi ahli desain, ahli materi, dan ahli media. Hal ini dilakukan, karena untuk memastikan produk ini sudah layak atau belum untuk digunakan oleh siswa. Setelah validasi oleh ahli desain, ahli isi, dan ahli media, kemudian dilakukan evaluasi orang per orang (3 orang siswa), uji kelompok kecil (6 orang siswa), dan uji lapangan (30 orang siswa).

\section{HASIL PENELITIAN}

Berdasarkan tujuan penelitian ini, peneliti telah melakukan pengembangan media pembelajaran berbasis android pada mata pelajaran sosiologi kelas XI SMA sesuai dengan prosedur model pengembangan prosedural Sugiyono dan selanjutnya telah menguji kelayakan produk yang meliputi kevalidan dan kepraktisan media pembelajaran berbasis android.

\section{Tahap Perancangan}

Dalam tahap perancangan, peneliti akan melakukan beberapa kegiatan diantaranya yaitu analisis kebutuhan, yakni peneliti melakukan observasi untuk melihat kesenjangan yang terjadi, kemudian mengumpulkan data dan informasi berkenaan dengan penelitian. Berdasarkan data dan informasi yang diperoleh, selanjutnya peneliti mulai menyusun Garis Besar Isi Media (GBIM) dan Jabaran Materi (JM) yang merupakan acuan utama dalam tahap pengembangan media dan bahan ajar. Langkah selanjutnya setelah GBIM dan Jabaran Materi telah disusun yaitu penulisan naskah (storyboard) sesuai dengan jenis media yang berisi berbagai ketentuan mengenai produksi.

\section{Tahap Produksi Media}

Dalam tahap ini, peneliti melakukan persiapan sebelum proses produksi. Persiapan yang peneliti lakukan yaitu menyusun kebutuhan peralatan dan bahan produksi. Selanjutnya, peneliti mulai melakukan pembuatan produk yang nantinya akan digunakan sebagai sumber belajar. Pada saat pembuatan produk dengan aplikasi Adobe Flash CS 6, dimulai dari pembuatan intro sampai penutup produk, kemudian diisi dengan materi yang sudah dipilih dengan memperhatikan teks, suara, gambar serta animasi yang ingin ditampilkan, sehingga media pembelajaran lebih menarik dan interaktif.

Berikut tampilan produk media pembelajaran berbasis android sebelum dilakukan evaluasi:

\section{Halaman Login}

Halaman ini menampilkan logo media pembelajaran, tampilan ini berisi teks atau judul media pembelajaran yang 
Edutainment : Jurnal Ilmu Pendidikan dan Kependidikan

Volume 8 Nomor 1 Edisi Januari - Juni 2020

dikembangkan, tombol untuk memulai media pembelajaran tersebut.

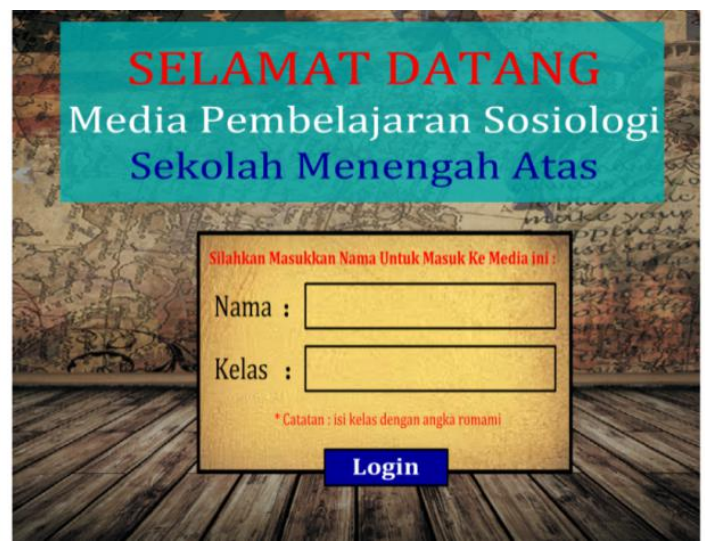

Gambar 1. Tampilan Halaman Login

\section{Halaman Menu Utama}

Halaman menu utama berisi gambar, animasi teks berjalan, dan beberapa tombol menu yang berfungsi untuk mengakses menu yang diinginkan.

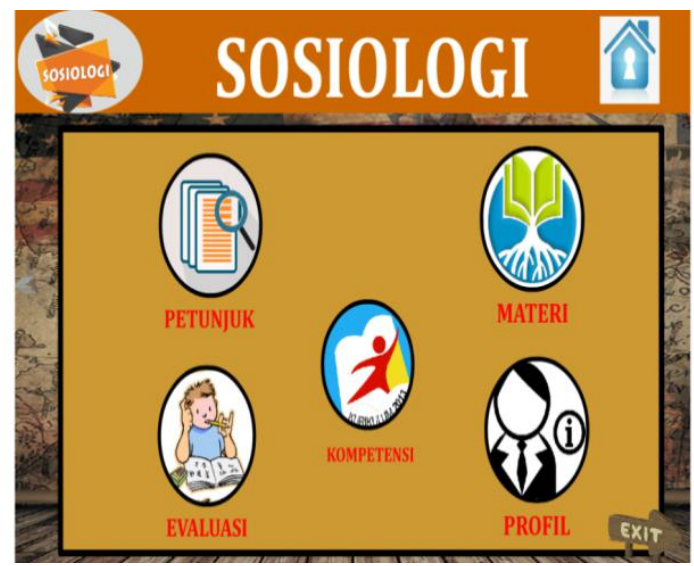

Gambar 2. Tampilan Halaman Menu Utama

Tombol-tombol menu yang terdapat di halaman menu utama tersebut antara lain tombol, petunjuk, kompetensi, materi, evaluasi, pengembang, dan keluar.

\section{Halaman Petunjuk}

Halaman petunjuk merupakan tampilan yang berisi petunjuk penggunaan media.

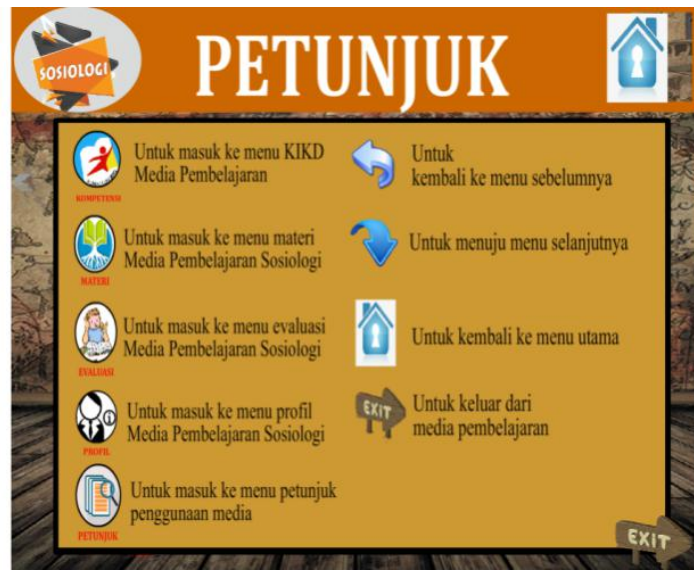

Gambar 3. Tampilan Halaman Petunjuk

\section{Halaman Kompetensi}

Halaman kompetensi berisi informasi mengenai, standar kompetensi dan kompetensi dasar mata pelajaran.

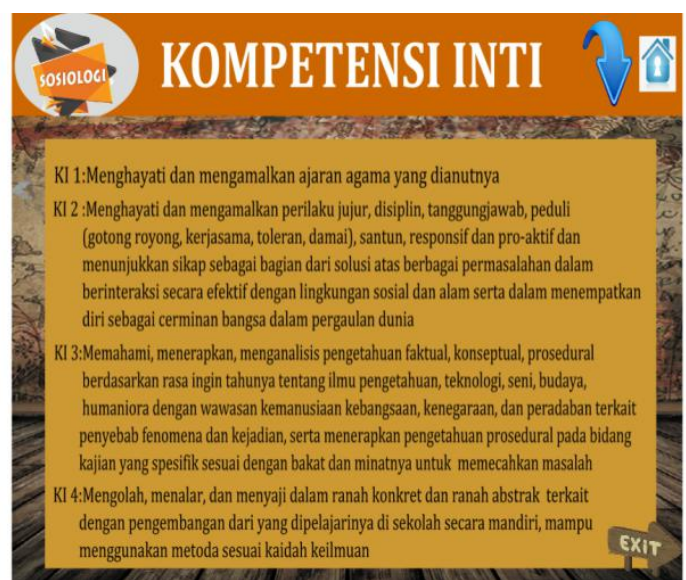

Gambar 4. Tampilan Halaman

Kompetensi Inti 
Edutainment : Jurnal Ilmu Pendidikan dan Kependidikan

Volume 8 Nomor 1 Edisi Januari - Juni 2020

\section{Halaman Materi}

Awal tampilan halaman materi ini akan tampil tombol Bab 1, Bab 2, Bab 3, dan Bab 4. Pengguna bisa memilih materi pelajaran yang diinginkan dengan mengklik tombol Bab 1, Bab 2, Bab 3, dan Bab 4.

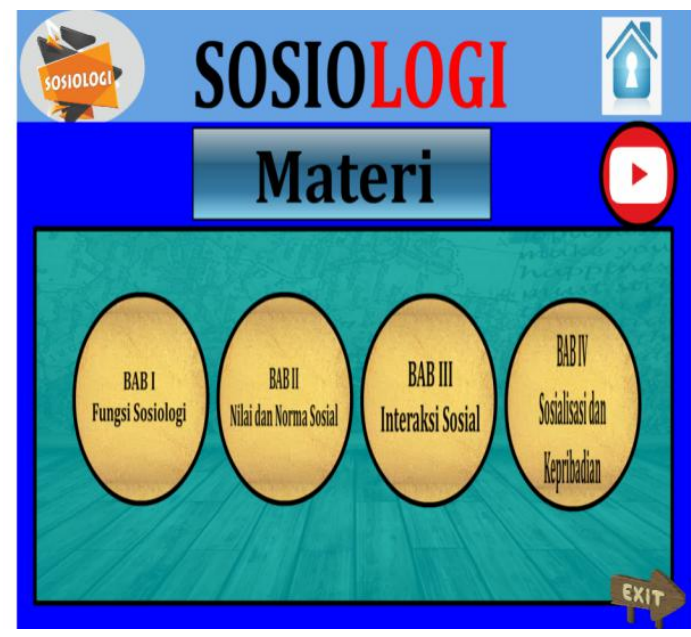

Gambar 5. Tampilan Halaman Materi

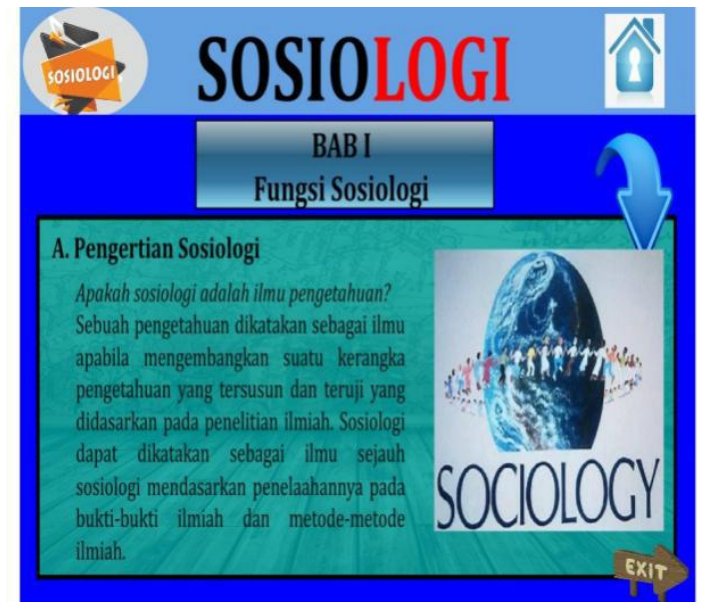

Gambar 6. Tampilan Halaman Materi

Adapun dalam halaman materi ini menjelaskan tentang materi yang di sesuaikan dengan standar kompetensi dan kompetensi dasar pada silabus.

\section{Halaman Evaluasi}

Awal tampilan halaman evaluasi terdapat tombol pilihan ganda untuk mengerjakan soal, untuk dapat memulai evaluasi pengguna harus menekan tombol pilihan ganda.

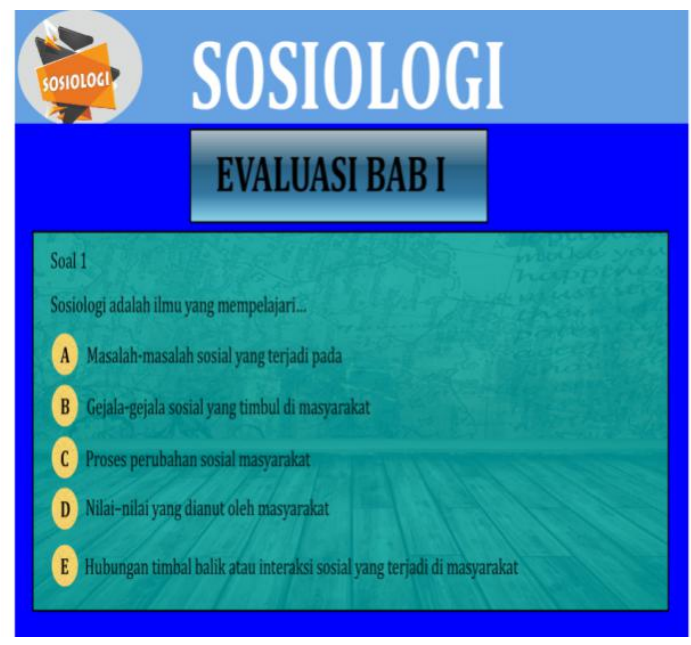

Gambar 7. Tampilan Halaman Soal-soal Latihan

Pada frame ini berisi tampilan bentuk evaluasi yang disajikan pada media pembelajaran.

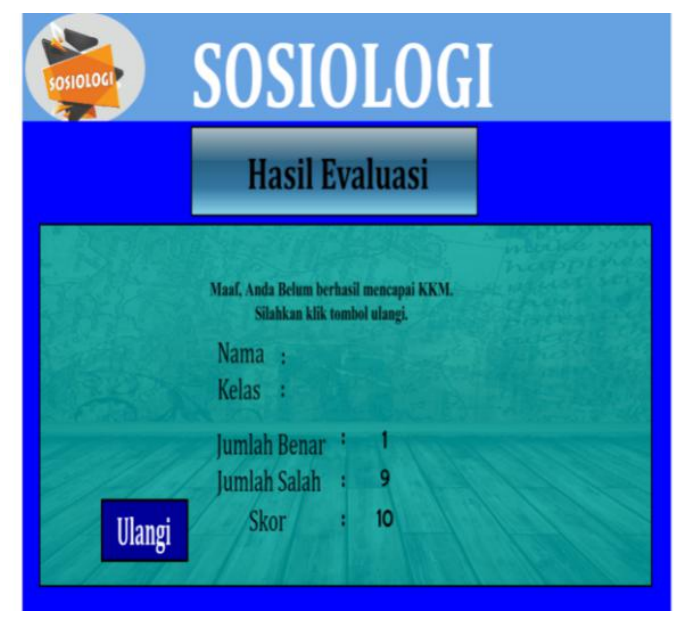

Gambar 8. Tampilan Halaman Hasil Latihan 
Edutainment : Jurnal Ilmu Pendidikan dan Kependidikan

Volume 8 Nomor 1 Edisi Januari - Juni 2020

Apabila soal evaluasi telah selesai dikerjakan maka akan muncul tampilan jumlah skor hasil dari mengerjakan soal, dan ada tombol untuk mengulangi soal evaluasi.

\section{Tahap Evaluasi Media}

Setelah produk dikembangkan, peneliti kemudian melakukan penilaian produk yang terdiri dari evaluasi ahli (expert), evaluasi orang perorang, evaluasi kelompok kecil dan uji coba lapangan. Pada evaluasi ahli, peneliti melakukannya untuk mengukur baik atau tidaknya media pembelajaran berbasis android yang telah dikembangkan. Pada tahap evaluasi ahli (expert) ini terdiri dari uji ahli media, ahli materi, dan ahli desain pembelajaran.

\section{Ahli Media}

Validasi produk dilakukan pada tanggal 18 Juli 2019 dengan hasil sebagai berikut:

Tabel 3. Hasil Validasi Produk oleh Ahli Media

\begin{tabular}{clc}
\hline No. & \multicolumn{1}{c}{ Indikator } & Nilai \\
\hline 1. & Tampilan Teaser/Opening & 84 \\
pada media pembelajaran & \\
& $\begin{array}{l}\text { Sosiologi mampu menarik } \\
\text { perhatian peserta didik. }\end{array}$ & \\
\hline 2. & $\begin{array}{l}\text { Kesesuaian animasi dan } \\
\text { warna Teaser/Opening } \\
\text { dengan produk media } \\
\text { pembelajaran. }\end{array}$ & \\
\hline 3. & $\begin{array}{l}\text { Kesesuaian ukuran dan } \\
\text { jenis huruf pada media } \\
\text { pembelajaran. }\end{array}$ \\
\hline
\end{tabular}

\begin{tabular}{|c|c|c|}
\hline No. & Indikator & Nilai \\
\hline 4. & $\begin{array}{l}\text { Kejelasan kalimat pada } \\
\text { materi dan latihan soal di } \\
\text { dalam media pembelajaran. }\end{array}$ & 80 \\
\hline 5. & $\begin{array}{l}\text { Ketajaman penggunaan } \\
\text { gambar di halaman materi } \\
\text { pada media pembelajaran. }\end{array}$ & 79 \\
\hline 6 & $\begin{array}{l}\text { Ketepatan penempatan } \\
\text { gambar pada media } \\
\text { pembelajaran. }\end{array}$ & 78 \\
\hline 7. & $\begin{array}{l}\text { Gambar pada materi sesuai } \\
\text { dengan mata pelajaran } \\
\text { Sosiologi. }\end{array}$ & 77 \\
\hline & $\begin{array}{l}\text { Evaluasi sesuai dengan } \\
\text { materi yang ada dalam } \\
\text { media pembelajaran. }\end{array}$ & 76 \\
\hline 9. & $\begin{array}{l}\text { Penggunaan musik tidak } \\
\text { mengganggu } \\
\text { penggunaan media. }\end{array}$ & 80 \\
\hline 10. & $\begin{array}{l}\text { Musik yang ada dalam } \\
\text { media pembelajaran } \\
\text { berbasis android mata } \\
\text { pelajaran Sosiologi } \\
\text { memberi semangat dan } \\
\text { motivasi siswa. }\end{array}$ & 83 \\
\hline 11. & $\begin{array}{l}\text { Pemakaian warna dalam } \\
\text { tampilan media sudah tepat } \\
\text { proposinya. }\end{array}$ & 80 \\
\hline \multicolumn{2}{|c|}{ Jumlah } & 885 \\
\hline \multicolumn{2}{|c|}{ Rata-rata } & 80,45 \\
\hline \multicolumn{2}{|c|}{ Keterangan } & Baik \\
\hline \multicolumn{2}{|c|}{ Predikat } & $\mathrm{B}$ \\
\hline
\end{tabular}

Berdasarkan hasil validasi oleh ahli media, jumlah nilai dari 11 pernyataan adalah 885 dan rata-rata nya yaitu 80,45 dengan kriteria "Baik".

\section{Ahli Desain \\ Validasi produk oleh ahli desain dilakukan pada tanggal 17 Juli 2019 dengan hasil sebagai berikut.}


Edutainment : Jurnal Ilmu Pendidikan dan Kependidikan

Volume 8 Nomor 1 Edisi Januari - Juni 2020

Tabel 4. Hasil Validasi Produk oleh Ahli

Desain

Berdasarkan hasil validasi oleh ahli

\begin{tabular}{ccc}
\hline No. & \multicolumn{1}{c}{ Indikator } & Nilai \\
\hline 1. & $\begin{array}{l}\text { Produk media pembelajaran } \\
\text { berbasis android disajikan } \\
\text { dengan terstruktur. }\end{array}$ & 80 \\
\hline
\end{tabular}

2. Kesesuaian urutan penyajian 85 desain materi sesuai dengan Kompetensi Inti dan Kompetensi Dasar.

Kesesuaian urutan penyajian 80 desain soal-soal di dalam media pembelajaran berbasis android mata pelajaran Sosiologi.

4. Desain media pembelajaran 85 efektif digunakan untuk mencapai kompetensi pembelajaran.

5. Kesesuaian desain dengan 85 media pembelajaran dalam penyampaian materi pada mata pelajaran Sosiologi.

\begin{tabular}{llr} 
6. & $\begin{array}{l}\text { Desain pada } \\
\text { pembelajaran }\end{array}$ & $\begin{array}{r}\text { media } \\
\text { efisien }\end{array}$ \\
digunakan untuk mencapai & \\
kompetensi pembelajaran. & \\
\hline
\end{tabular}

7. Desain dalam Media 80 pembelajaran yang dibuat sesuai dengan karakteristik siswa kelas X IPS.

8. Kesesuaian tampilan warna 85 yang digunakan dengan karakteristik siswa kelas $\mathrm{X}$ IPS.

9. Desain Soal dalam evaluasi 83 sesuai dengan Kompetensi Inti.

10. Desain Soal dalam evaluasi 80 sesuai dengan Kompetensi Dasar.

11. Desain Evaluasi yang dibuat 80 sesuai dengan materi.

\begin{tabular}{lc}
\hline Jumlah & 901 \\
\hline Rata-rata & 81,90 \\
\hline Keterangan & Baik \\
\hline Predikat & B \\
\hline
\end{tabular}


Edutainment : Jurnal Ilmu Pendidikan dan Kependidikan

Volume 8 Nomor 1 Edisi Januari - Juni 2020

\begin{tabular}{llc}
\hline \multicolumn{3}{l}{ media pembelajaran sesuai } \\
dengan isi materi.
\end{tabular}

Berdasarkan hasil validasi oleh ahli materi, jumlah nilai dari 12 pernyataan yaitu 1061 dan rata-rata nya yaitu 88,41 dengan kriteria "Baik Sekali”.

\section{Rekapitulasi Uji Perorangan, Uji kelompok kecil dan Uji Lapangan}

Analisis data ini digunakan untuk mengukur tingkat kelayakan produk yang dihasilkan. Adapun hasilnya sebagai berikut:

Tabel 6. Rekapitulasi Hasil Uji Coba

\begin{tabular}{cccl}
\hline Skala & Skor & persentase & Kategori \\
\hline Perorangan & 4390 & $91,45 \%$ & Sangat \\
& & & Baik \\
\hline Kecil & 7254 & $86,35 \%$ & Sangat \\
& & & Baik \\
\hline Besar & 26830 & $89,43 \%$ & Sangat \\
& & & Baik \\
\hline
\end{tabular}

Berdasarkan tabel 6 di atas dapat di simpulkan pada uji perorangan persentase untuk produk media pembelajaran berbasis Android yaitu 91,45\% dengan kriteria "Baik Sekali". Kemudian hasil uji skala kecil hasilnya yaitu $86,35 \%$. Jadi, persentase untuk keseluruhan produk Media Pembelajaran Berbasis Android dengan Menggunakan Aplikasi Adobe Flash CS 6 pada mata pelajaran Sosiologi kelas X SMA yaitu $86,35 \%$ dengan kriteria "Baik Sekali". Lalu hasil.analisis data uji coba skala lapangan hasilnya yaitu 89,43\%. dengan kriteria "Baik Sekali”. Dengan demikian produk yang dikembangkan layak untuk digunakan dalam pembelajaran di sekolah.

\section{PEMBAHASAN}

Media pembelajaran berbasis android ini dikembangkan sebagai alternatif atau sebagai pelengkap pembelajaran konvensional tatap muka dengan memanfaatkan smartphone android. Menurut Gerlach dan Ely (Arsyad, 2011:3), “Media apabila dipahami secara garis besar adalah manusia, materi, atau kejadian yang membangun kondisi yang membuat siswa mampu memperoleh pengetahuan, keterampilan, dan sikap. Sedangkan menurut Rusman (2011:160), “Media pembelajaran merupakan suatu teknologi pembawa pesan yang dapat digunakan oleh guru untuk menyampaikan pelajaran". Jadi, media pembelajaran berbasis android ini diharapkan dapat menjadi pelengkap media konvensional yang lainnya dalam pembelajaran dimanapun dan kapanpun siswa berada dengan syarat android terhubung dengan internet. 
Edutainment : Jurnal Ilmu Pendidikan dan Kependidikan

Volume 8 Nomor 1 Edisi Januari - Juni 2020

Pembelajaran dengan menggunakan media berbasis android ini membuat peserta didik dapat meningkatkan perhatian dalam memahami materi pelajaran, membuat pembelajaran menjadi lebih menarik dan dapat memotivasi peserta didik. Hal tersebut sejalan dengan fungsi media sebagai motivasi ekstrinsik yang dinyatakan oleh Adnyana (2013) bahwa dalam kaitannya dengan proses belajar mengajar, peserta didik akan dipengaruhi oleh rangsangan dari luar yang menjadi motivasi atau pendorong untuk membantu belajar peserta didik meningkatkan hasil belajar.

\section{KESIMPULAN}

Produk yang dihasilkan merupakan pengembangan media pembelajaran berbasis android kelas X SMA. Dalam mengembangkan media pembelajaran berbasis android ini peneliti telah melakukan prosedur atau tahapan sesuai dengan model yang dipakai yaitu model Prosedural yang terdiri dari tiga tahap antara lain: pertama tahap perencangan, kedua tahap produksi, dan yang ketiga evaluasi.

Kemudian dilanjutkan dengan tahap uji coba lapangan yang sesuai dengan model Evaluasi Pramaster yaitu evaluasi ahli yang dilakukan sebanyak 3 tahap. Hasil validasi dari (ahli media, ahli desain, dan ahli materi) dengan hasil persentase masing-masing yaitu $80,45 \% ; 81,90 \%$; dan
$88,41 \%$ dengan kriteria baik. Hasil uji coba skala perorangan (one-to-one) mendapatkan hasil persentase $91,45 \%$ dengan predikat sangat baik, hasil uji coba skala kecil (small group) mendapatkan hasil persentase $86,35 \%$ dengan predikat sangat baik, dan Hasil uji coba skala besar (field test) mendapatkan hasil persentase $89,43 \%$ dengan predikat sangat baik.

Berdasarkan hasil penelitian dan pembahasan tentang pengembangan media pembelajaran berbasis android pada mata pelajaran Sosiologi, maka dapat peneliti simpulkan bahwa produk media pembelajaran berbasis android pada mata pelajaran Sosiologi ini layak untuk digunakan di lapangan, karena sudah tergolong baik dan layak sebagai media pembelajaran siswa dan diterapkan oleh penggunanya di kelas $\mathrm{X}$ dengan kelebihan media pembelajaran berbasis android ini lebih menarik untuk dijadikan media pembelajaran, penggunaan warna dan background sebagai daya tarik media untuk siswa, menunjang siswa untuk belajar mandiri dan lebih aktif lagi pada bagian evaluasi, gambar terlihat jelas dalam isi materi media.

Kekurangan media pembelajaran ini yaitu tidak dapat diakses secara online, sehingga untuk peneliti selanjutnya dapat mengembangkan media pembelajaran berbasis android agar dapat juga diakses secara online. 
Edutainment : Jurnal Ilmu Pendidikan dan Kependidikan

Volume 8 Nomor 1 Edisi Januari - Juni 2020

\section{DAFTAR PUSTAKA}

Adnyana, I. G. (2013). Penggunaan EDI Scanner sebagai Media Pembelajaran untuk Meningkatkan Minat, Motivasi dan Prestasi Belajar Mahasiswa. Jurnal Pendidikan Vokasi Vol 3, Nomor 2, Juni 2013, 192-209.

Arsyad, A. (2011). Media Pembelajaran. Jakarta: Rajawali Pers.

Hamdani. (2011). Strategi Belajar Mengajar. Bandung: Pustaka Setia.

Istiyanto, J. E. (2013). Pemrograman Smartphone Menggunaakan SDK Android dan Hacking Android. Yogyakarta: Graha Ilmu.

Kuswanto. J dan Radiansyah. F. (2018). Media Pembelajaran Berbasis Android pada Mata Pelajaran Sistem Operasi Jaringan Kelas XI. Jurnal Media Infotama vol. 14 no. 1, hlm. 15-20.

Muyaroah. S dan Fajartia. M. (2017) Pengembangan Media Pembelajaran Berbasis Android dengan menggunakan Aplikasi Adobe Flash CS 6 pada Mata Pelajaran Biologi. Innovative Journal of Curriculum and Educational Technology (IJCET) vol. 6 no. 2 , hlm. 79-83.

Ningsih, S dan Adesti. A. (2019). Pengembangan Mobile Learning Berbasis Android pada Mata Kuliah Strategi Pembelajaran Universitas Baturaja. Jurnal Kajian Teknologi Pendidikan vol. 4, no. 2, hlm.163-172.

Noer, A. R. (2016). Pelaksanaan Program Lintas Minat Sosiologi pada Kurikulum 2013 (Studi Kasus Pada Siswa Kelas X MIPA di SMA N 1 Bulakamba Kabupaten Brebes Tahun Pelajaran 2015/2016). Skripsi Universitas Negeri Semarang.
Nurgiyantoro, B. (2010). Penilaian Pembelajaran Berbasis Kompetensi. Yogyakarta: BPEE.

Rusman, dkk. (2012). Pembelajaran Berbasis Teknologi Informasi dan Komunikasi. Jakarta: Rajawali Pers.

Safaat, N. (2015). Android Pemograman Aplikasi Android Mobile Smartphone dan Tablet PC Berbasis Android. Bandung: INFORMATIKA.

Sudijono, Anas. (2014). Pengantar Statistik Pendidikan. Jakarta: PT Raja Grafindo Persada.

Sugiyono. (2012). Metode Penelitian Pendidikan Kuantitatif, Kualitatif dan $R$ dan D. Bandung: Alfabeta.

Tegeh, I Made dan I Made Kirna. (2014). Metode Penelitian Pengembangan Pendidikan. Singaraja: Universitas Pendidikan Ganesha Singaraja. 